\title{
Comprehensive Genetic Analysis Results of TSC1/TSC2 Genes in Patients with Clinical Suspicion of Tuberous Sclerosis Complex and Definition of 3 Novel Variants
}

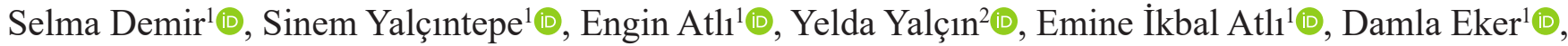 \\ Yasemin $\mathrm{Karal}^{3}{ }^{(1)}$, Hakan Gürkan ${ }^{1}$ (1)
}

\author{
${ }^{1}$ Department of Medical Genetics, Trakya University School of Medicine, Edirne, Turkey \\ ${ }^{2}$ Department of Medical Genetics, Samsun Ondokuz Mayıs University School of Medicine, Samsun, Turkey \\ ${ }^{3}$ Department of Pediatric Neurology, Trakya University School of Medicine, Edirne, Turkey
}

Background: Tuberous Sclerosis Complex is an autosomal dominant multi-system disorder with an incidence of about 1 in 6000 live births. Defects in either TSC1 (* 605284) or TSC2 (* 191092) genes encoding the components of the Tuberous Sclerosis Complex are responsible for the disease. Therefore, consideration of TSC1/TSC2 pathogenic variations is recommended in the updated diagnostic criteria of Tuberous Sclerosis Complex.

Aims: To present the TSC1/TSC2 screening results of a mixed patient population as well as possible new variants in 23 cases from 20 different families who were referred to our Genetic Diseases Diagnosis Center with the signs and symptoms of Tuberous Sclerosis Complex.

Study design: Retrospective, cross-sectional study.

Methods: Germline TSC1/TSC2 variants were screened in DNA samples extracted from peripheral blood samples of 23 patients from 20 unrelated families using targeted high-throughput sequencing and multiplex ligation-dependent probe amplification methods. The variants identified were classified according to ACMG 2015 guidelines.

Results: In total, 5 different pathogenic/likely pathogenic changes have been defined. All these pathogenic/likely pathogenic variants were located in the TSC2 gene. Three of the pathogenic/likely pathogenic variants were novel. Two patients who are twin sisters were found to have TSC2/PKD1 contiguous deletion syndrome. One of the 3 novel variants was a mosaic in-frame deletion. We did not identify any pathogenic variants of the TSC1 gene.

Conclusion: The novelty of most of the variants found, including a mosaic likely pathogenic variant, and the presence of a large genomic rearrangement, supports the importance of a comprehensive approach in analyzing TSC1/TSC2 genes. Genetic diagnosis should be performed with caution, considering the possibility of mosaic variants with low allelic fractions.

\section{INTRODUCTION}

Tuberous sclerosis complex (TSC), first described in $1862,{ }^{1}$ is a clinically and phenotypically variable disease affecting many different tissue and organ systems. Patients may manifest skin lesions, or have anomalies of the brain, kidney, heart, and lung. The incidence of TSC is about 1 in 6000 live births. ${ }^{2}$ Defects in the TSC1 (* 605284) or TSC2 (* 191092) genes are responsible for the disease. $^{3-6}$
The TSC, formed by the hamartin protein encoded by the TSC1 gene and the tuberin protein encoded by the TSC2 gene, has essential roles in metabolism, protein synthesis, cell growth, and angiogenesis. Loss of function of TSC1/TSC2 tumor suppressor genes results in uncontrolled cell growth and tumors due to overactivation of mTORC1 (mechanistic target of rapamycin complex 1). ${ }^{7}$ According to updated diagnostic criteria, TSC can be diagnosed by clinical features, as well as by the presence of a heterozygous

Corresponding author: Selma Demir, Department of Medical Genetics, Trakya University School of Medicine, Edirne, Turkey e-mail: selmademir1980@gmail.com

Received: April 16, 2021 Accepted: August 13, 2021 Available Online Date: September 28, 2021 • DOI: 10.5152/balkanmedj.2021.21092

Available at www.balkanmedicaljournal.org

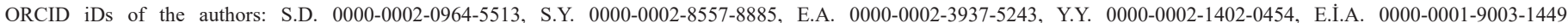
D.E. 0000-0001-7563-118X, Y.K. 0000-0003-0096-6676, H.G. 0000-0002-8967-6124.

Cite this article as:

Demir S, Yalçıntepe S, Atlı E, et al. Comprehensive genetic analysis results of TSC1/TSC2 genes in patients with clinical suspicion of tuberous sclerosis complex and definition of 3 novel variants. Balkan Med J.; 2021; 38(6):341-347.

Copyright@Author(s)-Available online at http://balkanmedicaljournal.org/ 
pathogenic variant in the TSC1 or TSC 2 genes. ${ }^{8}$ The clinical diagnostic criteria include 2 different subgroups called major and minor features. The major features include; angiofibroma, fibrous cephalic plaque, hypomelanotic macules, ungual fibromas, cortical dysplasia, shagreen patch, multiple retinal hamartomas, subependymal nodules or giant cell astrocytoma, cardiac rhabdomyoma, lymphangioleiomyomatosis (LAM), and angiomyolipomas. The minor features include confetti-like skin lesions, dental pits, intraoral fibromas, retinal achromic patch, multiple renal cysts, and nonrenal hamartomas. Two major features or 1 major feature with 2 or more minor features are needed for a definite clinical diagnosis. One major feature together with 2 or more minor features is required for "possible diagnosis." Beyond these minor and major clinical criteria, there is a wide range of signs and symptoms that have been related to abnormalities of TSC listed in the Human Phenotype Ontology (HPO) and Online Mendelian Inheritance in Man databases. ${ }^{9}$ For a definite diagnosis of TSC, identifying a TSC1 or TSC2 pathogenic variation is sufficient. Therefore, genetic analysis of TSC1 and TSC2 genes has great importance in diagnosing TSC ${ }^{8}$ (Table 1).

Genetic analysis of TSC1/TSC2 genes has been challenging for a long time due to the large size of the TSC 2 gene. ${ }^{10}$ High-throughput

TABLE 1. Diagnostic Criteria for Tuberous Sclerosis Complex According to Updated Recomendations ${ }^{6}$

\section{A. Genetic Diagnostic criteria}

Identifying either a TSC1/TSC2 pathogenic variant in DNA from normal tissue is sufficient to make a definite diagnosis of the tuberous sclerosis complex (TSC). However, TSC1 or TSC2 variants whose effect on function is less certain are insufficient to make a definite diagnosis of TSC.

B. Clinical Diagnostic Criteria

\begin{tabular}{ll}
$\begin{array}{l}\text { Major Features } \\
\text { Hypomelanotic macules }(\geq 3 \text {, at least } 5 \mathrm{~mm} \text { in } \\
\text { diameter) }\end{array}$ & $\begin{array}{l}\text { Minor Features } \\
\text { "Confetti" skin lesions }\end{array}$ \\
$\begin{array}{l}\text { Angiofibromas }(\geq 3) \text { or fibrous cephalic plaque } \\
\text { Ungual fibromas }(\geq 2)\end{array}$ & $\begin{array}{c}\text { Dental enamel pits }(>3) \\
\text { Intraoral fibromas }(\geq 2)\end{array}$ \\
Shagreen patch & Retinal achromic patch \\
Multiple retinal hamartomas & Multiple renal cysts \\
Cortical dysplasia & Nonrenal hamartomas \\
Subependymal nodules & \\
Subependymal giant cell astrocytoma & \\
Cardiac rhabdomyoma & \\
Lymphangioleiomyomatosis (LAM) & \\
$\begin{array}{l}\text { Angiomyolipomas }(\geq 2) \\
\text { Diagnosis According to Revised Diagnostic Criteria for Tuberous Sclerosis } \\
\text { Complex }\end{array}$ & \\
Definite TSC & Two major features or \\
& 1 major feature with \\
Possible TSC & $\geq 2$ minor features \\
\hline
\end{tabular}

TSC, tuberous sclerosis complex. sequencing (HTS) analysis, which has become increasingly common in both research and clinical practice in the last decade, provides essential advantages in diagnosing TSC due to its ability in simultaneous analysis of large genes. Determining the genetic background of the disease is critical for precise genetic counseling. ${ }^{11}$ In about $3 \%$ of the patients, the underlying molecular defect may be gross deletions/duplications. ${ }^{6}$ These rearrangements are more frequent in the TSC2 than in the TSC1 gene and may involve both the TSC 2 and the PKD1 genes, adjacent genes located on chromosome $16 .{ }^{12-15}$ The multiplex ligation-dependent probe amplification (MLPA) method is a well-known method to detect large genomic deletions/duplications in a targeted manner. ${ }^{16}$ Therefore, it is a valuable method for detecting TSC1/TSC2 deletions/duplications. ${ }^{14}$ This study aimed to present the results of a comprehensive genetic analysis of 23 patients from 20 different families referred to our Genetic Diseases Diagnosis Center with a clinical suspicion of TSC. By reporting 3 novel and 1 known causative variant defined by HTS and a TSC2/PKD1 contiguous deletion syndrome characterized by MLPA, this study emphasizes the importance of using both HTS and MLPA in the genetic analysis of TSC1/TSC2 genes.

\section{MATERIAL AND METHODS}

The high-throughput sequencing and MLPA analysis results of the TSC1 and TSC 2 genes of 23 patients ( 8 males, 15 females, mean age: $10.6 \pm 11.6$, Table 2 ) from 20 different families who were tested in the Genetic Diseases Diagnosis Center between February 2013 and January 2019 were included in this study. Written informed consent was obtained from the patients or the legal guardians of the patients younger than 18 years old. The Institutional Ethical Board approved this study with the decision number BAEK-2021/45.

\section{Whole Blood Collection and DNA Isolation}

Peripheral blood samples were collected from patients with informed consent forms for genetic investigation. DNA was isolated from EDTA blood samples by the BioRobot EZ1 system (Qiagen Hilden, Germany), according to the manufacturer's instructions. The Qubit 2.0 fluorometer (Invitrogen, Life Technologies) was used for quantity and quality control of isolated DNA samples prior to library construction.

TABLE 2. Clinical/Phenotypic and Demographic Features of our Study Population

\begin{tabular}{lc}
\hline Clinical/phenotypic and demographic features & $\mathrm{N}(\%)$ \\
\hline Renal abnormalities & $8(34.78)$ \\
Cranial abnormalities & $11(47.82)$ \\
Dermatologic findings & $10(43.47)$ \\
Rhabdomyoma & $3(13.04)$ \\
Epilepsy & $12(51.17)$ \\
Gender & \\
$\quad$ Female & $15(65.21)$ \\
Male & $8(34.78)$ \\
\hline
\end{tabular}


High-Throughput Sequencing Library Construction The primers targeting the coding regions of TSC1 and TSC2 genes with $20 \mathrm{bp}$ intron padding were designed with the Ion AmpliSeq Designer (Life Technologies). Amplicon libraries were constructed with a mix including $4 \mu \mathrm{L}$ of $5 \mathrm{X}$ Ion AmpliSeq HiFi mix, $10 \mu \mathrm{L}$ of multiplexed primer pool, $10 \mathrm{ng}$ of gDNA per reaction, and 4 $\mu \mathrm{L}$ of molecular-grade water. The PCR mixes were subjected to thermal cycling conditions as follows: at $99^{\circ} \mathrm{C}$ for 2 minutes; $99^{\circ} \mathrm{C}$ for 15 seconds, $60^{\circ} \mathrm{C}$ for 4 minutes ( 19 cycles); and a final hold at $10^{\circ} \mathrm{C}$. Adapters and barcodes (Ion Xpress, Life Technologies) were ligated to the amplicons including partially-digested primers, and were prepared as described in the Ion AmpliSeq library preparation protocol. The Ion One Touch 2 System and the Ion One Touch ES Instruments (Life Technologies) were used for the production of Enriched, template-positive Ion Sphere Particles. Sequencing of enriched particles was performed on the PGM (Life Technologies) with 314 and 318 chips, according to the user guide for the Ion PGM sequencing 200 kit v2 (Life Technologies).

Torrent Suite Software v.5 (Life Technologies) was used for raw data processing, alignment, and variant calling. The hg19 human reference genome (Genome Reference Consortium GRCh37) was used as the reference genome.

Coverage analysis control was performed with the Ion Reporter's coverage analysis plugin. At least $20 \times$ coverage for targeted bases was accepted as reliable for variant calling. Samples under this threshold were repeated. Ion Reporter v5.0 software was used for annotating and filtering variants.

The amplicons of TSC1 and TSC2 genes of each sample were also checked manually with the help of the IGV 2.4 .8 program. ${ }^{17}$ For segregation analyses, primers covering the variant region of interest were designed in our laboratory. Amplicons obtained after the polymerase chain reaction were subjected to dideoxy chain-termination reaction using the BigDye Terminator v3.1 Cycle Sequencing Kit (Applied Biosystems, Foster City, CA, USA) following the manufacturer's protocol and sequenced with the ABI3130 XL (Applied Biosystems, Foster City, CA, USA) automatic capillary system.

\section{Multiplex Ligation-Dependent Probe Amplification} The P124-C3 and P337-B1 MLPA probe mixes (MRC-Holland, Amsterdam, the Netherlands) were used to test possible deletions/ duplications of the TSC1 and TSC2 genes. Ligation and amplification of ligated probes were performed following the manufacturer's protocol, and the products were separated on the ABI 3130 XL (Applied Biosystems, USA) capillary electrophoresis system. The sizes of the fragments were determined using the GeneMapper (Applied Biosystems, USA) program, and the results were analyzed with the Coffalyser software (MRC Holland).

In Silico Predictions and Variant Classification

The variants identified were classified according to ACMG 2015 guidelines $^{18}$ considering population frequencies, in gnomAD, ${ }^{19}$ ClinVar, ${ }^{20}$ and dbSNP $^{21}$ databases, HGMD ${ }^{22}$ database accessions, Leiden Open Variation accessions, ${ }^{23}$ previous reports, and in silico prediction tools.
$\mathrm{CADD}^{24}$ and MutationTaster ${ }^{25}$ were used to predict the pathogenic potential of all rare/novel variants. PhyloP ${ }^{26}$ was considered for conservation scores. MaxEntScan ${ }^{27}$ and GeneSplicer (http://www .cbcb.umd.edu/software/GeneSplicer/gene_spl.shtml) predictions were applied to the splicing variants.

\section{Statistical Analysis}

Descriptive analyses of variants and patient demographics were used for the frequency distributions. Mean age and standard deviations were calculated with $\mathrm{R}$ open software.

\section{RESULTS}

In total, 4 different pathogenic/likely pathogenic variants have been determined by HTS (Table 3). Two patients who were twin sisters had TSC2/PKD1 contiguous deletion syndrome with a heterozygous loss encompassing TSC2 33-42nd exons and PKD1-30/ PKD1-40 gene regions, defined by MLPA.

Three out of 4 variations defined by HTS were novel variants that were not previously reported elsewhere (Table 4). The TSC2 (NM_000548): c.1000_1002delGTG (p.Val334del) in-frame deletion defined in patient 4 was a mosaic variant with a ratio of $27 \%$. Sequencing analysis revealed decreased peak heights, confirming the mosaicism of this variant which was initially determined via HTS. This mosaic patient's parents did not have the TSC2 c.1000_1002delGTG (p.Val334del) deletion, as expected. The parents of patient 4 were also available for segregation analysis, which confirmed that the TSC2 c.4253dupC (p.Gln1419ThrfsTer105) variant, previously reported in the LOVD database, was a de novo variant. We did not define any pathogenic/ likely pathogenic variants of the TSC1 gene in our patients.

\section{DISCUSSION}

Tuberous sclerosis complex disease is caused by loss-of-function variants in either the TSC1 gene localized on the $9 \mathrm{q} 34$ region or in the TSC2 gene located on the $16 \mathrm{p} 13.3$ region. The revised tuberous sclerosis complex diagnostic criteria published in 2013 by the International Tuberous Sclerosis Complex Consensus Group include the screening of TSC1/TSC2 genes, emphasizing the importance of genetic screening of TSC genes in suspected patients. ${ }^{8}$ We have presented our genetic analysis results of 23 patients referred to our Genetic Diseases Diagnosis Center to be tested in terms of TSC1/ TSC2 variants that we analyzed both with HTS and MLPA methods. We found a known large deletion including partial regions of both TSC2 and PKD1 genes in twin sisters and defined 4 TSC2 variants, one of them being a mosaic in-frame deletion.

The TSC1 gene has 23 exons in its canonical transcript (NM_000368) and encodes the cell adhesion protein called hamartin, whereas the TSC2 gene encoding for tuberin is a relatively large gene comprising 42 exons in its canonical transcript. Previous studies have shown that the variant frequency and diversity of the TSC2 gene are higher than the TSC1 gene. Furthermore, TSC2 variants are associated with a more severe phenotype than those in TSC1. ${ }^{28,29}$ In 8 out of 23 patients, we identified pathogenic/likely pathogenic TSC2 variants. However, 
TABLE 3. High-Throughput Sequencing and Multiplex Ligation-Dependent Probe Amplification Screening Results and Clinical Features of the Patients

\begin{tabular}{|c|c|c|c|c|c|c|}
\hline $\begin{array}{l}\text { Patient } \\
\text { No. }\end{array}$ & Age/Gender & Genetic Screening Results & $\begin{array}{l}\text { Clinical/Phenotypic } \\
\text { Information }\end{array}$ & $\begin{array}{c}\text { Diagnosis } \\
\text { According to } \\
\text { TvSC Updated } \\
\text { Criteria Without } \\
\text { Genetic Testing } \\
\end{array}$ & $\begin{array}{l}\text { Diagnosis } \\
\text { According to } \\
\text { TSC Updated } \\
\text { Criteria After } \\
\text { Genetic Testing } \\
\end{array}$ & $\begin{array}{c}\text { Family History } \\
\text { of TSC }\end{array}$ \\
\hline $\mathrm{P} 1$ & $29 / \mathrm{F}$ & $\begin{array}{l}\text { Heterozygous c.4253dupC(p. } \\
\text { Gln1419ThrfsTer105) in TSC2 }\end{array}$ & $\begin{array}{l}\text { Bilateral renal multiple } \\
\text { angiomyolipomas } \\
\text { Thyroid nodules and bone } \\
\text { marrow involvement }\end{array}$ & NA & $\mathrm{DD}$ & No \\
\hline P 2 & $11 / \mathrm{M}$ & Heterozygous c. $138+2 \mathrm{~T}>\mathrm{A}$ in $T S C 2$ & $\begin{array}{l}\text { T2Flair increased signal } \\
\quad \text { intensity } \\
\text { Maxillary retention cysts } \\
\text { Bilateral renal } \\
\quad \text { angiomyolipomas } \\
\text { Epilepsy } \\
\text { Facial angiofibroma } \\
\text { Hypomelanocytic macules } \\
\text { Mild ID }\end{array}$ & DD & DD & $\begin{array}{r}\text { Yes, son of } \\
\text { patient } 3\end{array}$ \\
\hline P 3 & $53 / \mathrm{F}$ & & $\begin{array}{l}\text { T2Flair increased signal } \\
\text { intensity } \\
\text { Parenchymal renal disease? } \\
\text { Facial angiofibroma }\end{array}$ & NA & DD & $\begin{array}{l}\text { Yes, mother of } \\
\text { patient } 2\end{array}$ \\
\hline P 4 & $4 / F$ & $\begin{array}{l}\text { Mosaic } \\
\text { c. } 1000 \_1002 \text { delGTG (p.Val334del) in } \\
\quad T S C 2\end{array}$ & $\begin{array}{l}\text { Cranial cysts compatible } \\
\text { with TSC } \\
\text { Bilateral renal multiple } \\
\text { angiomyolipomas } \\
\text { Epileptic seizures }\end{array}$ & DD & $\mathrm{DD}$ & No \\
\hline P 5 & $21 / \mathrm{F}$ & $\begin{array}{l}\text { Heterozygous } \\
\text { c.5192dupA } \\
\text { (p.Asn1731LysfsTer44) in TSC2 }\end{array}$ & $\begin{array}{l}\text { T2Flair increased signal } \\
\text { intensity } \\
\text { Multiple hyperechogenic } \\
\text { nodules in liver } \\
\text { Bilateral renal } \\
\text { angiomyolipomas } \\
\text { Facial angiofibroma }\end{array}$ & DD & $\mathrm{DD}$ & $\begin{array}{c}\text { Yes, mother of } \\
\text { patient } 6\end{array}$ \\
\hline P 6 & $1 / \mathrm{M}$ & & $\begin{array}{l}\text { Cranial tubers } \\
\text { Angiomyolipoma in left } \\
\text { renal parenchyma } \\
\text { Hypomelanocytic macules }\end{array}$ & DD & DD & $\begin{array}{r}\text { Yes, son of } \\
\text { patient } 5\end{array}$ \\
\hline P 7 & $9 / \mathrm{F}$ & $\begin{array}{l}\text { Heterozygous deletion of TSC2 33-42nd } \\
\text { exons and PKD1-30/PKD1-40 gene } \\
\text { regions (TSC2/PKD1 contiguous } \\
\text { deletion syndrome) }\end{array}$ & $\begin{array}{l}\text { Cranial tubers } \\
\text { Polycystic kidney disease } \\
\text { Resistant epilepsy and } \\
\quad \text { learning disability } \\
\text { Hypomelanotic macules } \\
\text { Shagreen patches }\end{array}$ & DD & $\mathrm{DD}$ & $\begin{array}{l}\text { Yes, twin sister } \\
\quad \text { of patient } 8\end{array}$ \\
\hline P 8 & $9 / \mathrm{F}$ & $\begin{array}{l}\text { Heterozygous deletion of } T S C 233-42 \text { nd } \\
\text { exons and } \\
\text { PKD1-30/PKD1-40 gene regions (TSC2/ } \\
\text { PKD1 contiguous deletion syndrome) }\end{array}$ & $\begin{array}{l}\text { Cranial tubers } \\
\text { Polycystic kidney disease } \\
\text { ADHD } \\
\text { Epileptic seizures until } 4 \\
\quad \text { years old } \\
\text { Hypomelanotic macules }\end{array}$ & DD & $\mathrm{DD}$ & $\begin{array}{l}\text { Yes, twin sister } \\
\text { of patient } 7\end{array}$ \\
\hline P 9 & $14 / \mathrm{F}$ & None & $\begin{array}{l}\text { Gray matter heterotopia in } \\
\text { the left cerebral } \\
\text { hemisphere } \\
\text { Thornwaldt cyst } \\
\text { Epilepsy }\end{array}$ & NA & NA & No \\
\hline P 10 & $10 / \mathrm{M}$ & None & Epilepsy & NA & NA & No \\
\hline P 11 & $12 / \mathrm{M}$ & None & $\begin{array}{l}\text { Cortical dysplasia in brain } \\
\text { MRI } \\
\text { Epilepsy }\end{array}$ & NA & NA & No \\
\hline
\end{tabular}


TABLE 3. High-Throughput Sequencing and Multiplex Ligation-Dependent Probe Amplification Screening Results and Clinical Features of the Patients (Continued)

\begin{tabular}{|c|c|c|c|c|c|c|}
\hline $\begin{array}{l}\text { Patient } \\
\text { No. }\end{array}$ & Age/Gender & Genetic Screening Results & $\begin{array}{l}\text { Clinical/Phenotypic } \\
\text { Information }\end{array}$ & $\begin{array}{c}\text { Diagnosis } \\
\text { According to } \\
\text { TvSC Updated } \\
\text { Criteria Without } \\
\text { Genetic Testing }\end{array}$ & $\begin{array}{c}\text { Diagnosis } \\
\text { According to } \\
\text { TSC Updated } \\
\text { Criteria After } \\
\text { Genetic Testing }\end{array}$ & $\begin{array}{c}\text { Family History } \\
\text { of TSC }\end{array}$ \\
\hline $\mathrm{P} 12$ & $1 / \mathrm{M}$ & None & Epileptic seizures & NA & NA & No \\
\hline P 13 & $15 / \mathrm{M}$ & None & $\begin{array}{l}\text { Bilateral tubers in brain } \\
\text { MRI } \\
\text { Ewing Sarcoma } \\
\text { Facial angiofibroma } \\
\text { Hypopigmented macules }\end{array}$ & DD & DD & No \\
\hline Р 14 & $5 / \mathrm{F}$ & None & $\begin{array}{l}\text { Cranial hamartoma and } \\
\text { cortical dysplasia } \\
\text { Overgrowth } \\
\text { Macrocephaly } \\
\text { Frontal bossing } \\
\text { Multiple cafe-au-lait } \\
\text { macules }\end{array}$ & NA & NA & No \\
\hline P 15 & $1 / \mathrm{F}$ & None & Epileptic seizures & NA & NA & No \\
\hline P 16 & $1 \mathrm{~m} / \mathrm{M}$ & None & $\begin{array}{l}\text { Rhabdomyoma } \\
\text { Brother with the clinical } \\
\text { diagnosis of TSC ( } 8 \\
\text { years old) }\end{array}$ & NA & NA & Yes \\
\hline P 17 & $1 / \mathrm{M}$ & None & $\begin{array}{l}\text { Hypopigmented macule } \\
\quad(1 \mathrm{X}) \\
\text { Rhabdomyoma in prenatal } \\
\text { history }\end{array}$ & NA & NA & No \\
\hline P 18 & $1 / \mathrm{F}$ & None & $\begin{array}{l}\text { Hypopigmented macule } \\
\quad(1 \mathrm{X}) \\
\text { Epileptic seizures }\end{array}$ & NA & NA & No \\
\hline Р 19 & $5 / \mathrm{F}$ & None & $\begin{array}{l}\text { Epileptic seizures } \\
\text { Hypotonia } \\
\text { Growth retardation }\end{array}$ & NA & NA & \\
\hline P 20 & $10 / \mathrm{F}$ & None & $\begin{array}{l}\text { Epilepsy } \\
\text { Mental motor retardation. } \\
\text { Long face } \\
\text { Broad forehead } \\
\text { Flat philtrum } \\
\text { Dysplastic ears } \\
\text { Thin upper lip }\end{array}$ & NA & NA & No \\
\hline P 21 & $11 / \mathrm{F}$ & None & $\begin{array}{l}\text { Cranial tubers } \\
\text { Subependymal nodule- } \\
\text { Multiple hypopigmented }\end{array}$ & DD & DD & No \\
\hline P 22 & $11 / \mathrm{F}$ & None & $\begin{array}{l}\text { Cortical tubers in brain } \\
\text { MRI } \\
\text { Rhabdomyoma } \\
\text { Familial history of TSC }\end{array}$ & DD & $\mathrm{DD}$ & Yes \\
\hline Р 23 & $10 / \mathrm{F}$ & None & $\begin{array}{l}\text { T2Flair increased signal } \\
\text { intensity }\end{array}$ & NA & NA & No \\
\hline
\end{tabular}

F, female; M, male; m, months; ID, intellectual disability; NA, not available; DD, definite diagnosis; PD, possible diagnosis.

we did not find any pathogenic/likely pathogenic variants of the TSCl gene.

Mosaic variants of the TSC1 or TSC2 gene in TSC cases with various mutant allele frequencies have been reported in index cases and asymptomatic or mildly symptomatic parents of TSC cases. ${ }^{6}$ In 1 of our cases, the in-frame deletion in the TSC2 gene was evaluated as a mosaic with $27 \%$ mutant allele frequency according to the results of HTS. In our patient's brain magnetic resonance images, besides cysts compatible with TSC, there were angiolipomas and cysts in both kidneys, and she had a history of epileptic seizures. Thus, along with other TSC patients found to have in-frame deletions 
TABLE 4. Variants Defined in TSC2 Gene Via High-Throughput Sequencing Analysis

\begin{tabular}{|c|c|c|c|c|c|c|c|c|}
\hline $\begin{array}{l}\text { TSC } 2 \text { cDNA change } \\
\text { (NM_000548.5) }\end{array}$ & Predicted Protein Change & Variant Type & $\begin{array}{l}\text { CADD } \\
\text { Score }\end{array}$ & MutationTaster & MaxEntScan & GeneSplicer & gnomAD & ACMG Classification \\
\hline c. $138+2 \mathrm{~T}>\mathrm{A}$ & NA & Splice variant & 33 & Disease-Causing & $\begin{array}{l}\text { Likely } \\
\text { disrupted }\end{array}$ & Disrupting & $0 \%$ & $\begin{array}{l}\text { Likely pathogenic } \\
\text { (PVS1, PM2, PP1) }\end{array}$ \\
\hline c.1000_1002delGTG & p.(Val334del) & $\begin{array}{l}\text { In-frame } \\
\text { deletion }\end{array}$ & 21 & Disease-Causing & NA & NA & $0 \%$ & $\begin{array}{l}\text { Likely pathogenic } \\
\quad(\text { PM2, PM4, PM6) }\end{array}$ \\
\hline c. $4253 \mathrm{dupC}$ & p.(Gln1419ThrfsTer105) & $\begin{array}{l}\text { Frameshift } \\
\text { duplication }\end{array}$ & 44 & Disease-Causing & NA & NA & $0 \%$ & $\begin{array}{l}\text { Likely pathogenic } \\
\text { (PVS1, PM2) }\end{array}$ \\
\hline c.5192dupA & p.(Asn1731LysfsTer44) & $\begin{array}{c}\text { Frameshift } \\
\text { deletion }\end{array}$ & 34 & Disease-Causing & NA & NA & $0 \%$ & $\begin{array}{l}\text { Pathogenic (PP1, } \\
\text { PVS1, PM2) }\end{array}$ \\
\hline
\end{tabular}

NA, not available.

in the previous studies, ${ }^{29,30}$ the compatible clinical features of our patient confirm the pathogenicity of this novel mosaic in-frame deletion.

Splicing variants are common in TSC genes, and there are 134 pathogenic/likely pathogenic splice site variants of the TSC2 gene reported in the ClinVar database. The c. $138+2 \mathrm{~T}>\mathrm{A}$ splice variant of the TSC2 gene defined in our patient was inherited from his affected mother. Another single nucleotide change, c. $138+2 \mathrm{~T}>\mathrm{C}$, had been reported in patients with TSC in a previous report, ${ }^{31}$ but this variant was a novel variant neither reported in previous reports nor in public databases. The absence of this canonical splice cite variation (PVS1 according to ACMG 2015) in public databases (PM2 according to ACMG2015) and the presence of the variant both in the affected mother and son supported the pathogenicity of this novel splice site variation in our study.

The PKD1 gene and the TSC2 gene are located nearby on the $16^{\text {th }}$ chromosome in a tail-to-tail orientation. Variants and deletions of the PKD1 gene are associated with autosomal dominant polycystic kidney disease. ${ }^{32}$ In 1994, Brook-Carter et al reported TSC patients with deletions encompassing TSC2 and PKD1 genes, who have severe polycystic kidney disease in infancy. ${ }^{12}$ The phenotype, resulting from the large deletions including the TSC2 and $P K D 1$ genes, was then classified as TSC2/PKDI contiguous gene syndrome (PKDTS, MIM\#600273). In our patient cohort, we defined 2 patients with PKDTS who are twin sisters. Both of them had polycystic kidney disease. Previous studies reported that the deletion size does not correlate with clinical features. ${ }^{32}$ Unfortunately, it was impossible to compare genotype-phenotype correlation because we did not have any other patients except the twin sisters with PKDTS.

Tuberous sclerosis is a disease in which phenotypic diversity can be seen even among individuals carrying the same variant in the family, but in which penetrance is complete. ${ }^{6}$ In 2 of the familial patients in our cohort, the variants were inherited from affected mothers by their affected sons (patients 2 and 3; patients 5 and 6 ). The 2 other familial patients (patients 7 and 8) were twin sisters with TSC2/PKD1 contiguous deletion syndrome. All familial patients, even the twin sisters, had phenotypic discordance supporting the expressivity differences of TSC.
The pathogenic/likely pathogenic variant frequency was lower in this study, and there are some possible reasons. First of all, the patient group included not only the clinically diagnosed TSC patients but also the patients with signs and symptoms of TSC, listed in the HPO database. The variant definition rate of patients with a possible or definite diagnosis of TSC was $8 / 11$, reflecting the importance of clinical criteria prior to genetic evaluation. Epileptic seizures were more common in the variant-negative patient group. Whereas idiopathic epilepsy may be seen in most TSC patients, there may be very different causative genes underlying epileptic seizures. The high penetrance of epilepsy in our variant-negative patient group supports the reports suggesting the need for a multigene HTS panel for clarifying the genetic background of idiopathic epilepsy rather than testing only the TSC1 and TSC2 genes. ${ }^{33}$ As a second restrictive point, the designed kit used in this study has a $20 \mathrm{bp}$ intron padding. Studies indicate that the deep intronic variants may cause TSC, and it is possible that we might not define deep intronic mutations with the designed kit. ${ }^{33}$ The other possibility is that some low-level mosaic variants that can be seen in $\mathrm{TSC}^{34,35}$ may be missed even in the HTS analysis, detected with germline mutation-detection pipelines.

In conclusion, we reported 3 novel and 1 known TSC2 variants, including a mosaic in-frame deletion and a large deletion encompassing partial regions of both $T S C 2$ and $P K D 1$ genes, causing the PKDTS phenotype. Detection of mosaic variants can be challenging even in HTS analysis. Therefore, care should be taken that stringent quality parameters are being used in HTS analysis, keeping in mind the possibility of mosaic variants with low allelic fractions. We suggest that different clinical and phenotypic features of even the members of the same family, the novelty of most of the variants found, and the presence of a mosaic likely pathogenic variant even in the small-sized study population support the importance of a comprehensive approach in the genetic diagnosis of TSC. To our knowledge, this is the first study reporting both HTS and MLPA results of TSC1/TSC2 genes of the patients with signs and symptoms of TSC in the Turkish population.

Ethics Committee Approval: The Institutional Ethical Board approved this study with the decision number BAEK-2021/45.

Patient Consent for Publication: Written informed consent was obtained from the patients or the legal guardians of the patients younger than 18 years old. 
Peer Review: Hakan Gürkan and Yasemin Karal are the member of the Editorial Board of Balkan Medical Journal. However, They did not take place at any stage on the editorial decision of the manuscript.

Data-sharing Statement: The data that support the findings of this study are available from the corresponding author upon reasonable request.

Author Contributions: Concept - S.D., H.G.; Design - S.D., H.G.; Materials - S.D., E.A., Y.Y., E.İ.A., D.E., Y.K., H.G.; Data Collection and/or Processing - S.D., S.Y., E.A., Y.Y., E.İ.A., D.E., Y.K., H.G.; Analysis and/or Interpretation - S.D., S.Y., E.A., D.E., Y.K., H.G.; Literature Review - S.D., S.Y., H.G.; Writing - S.D., Y.Y., E.İ.A., D.E., Y.K., H.G.; Critical Review - S.Y., E.A., Y.Y., E.İ.A., H.G.

Conflict of Interest: The authors have no conflicts of interest to declare.

Funding: The authors declared that this study had received no financial support.

\section{REFERENCES}

1. von Recklinghausen F. Die Lymphelfasse und ihre Beziehung zum Bindegewebe [German]. Berlin: A. Hirschwald; 1862.

2. Crino PB, Nathanson KL, Henske EP. The tuberous sclerosis complex. N Engl J Med. 2006;355(13):1345-1356. [CrossRef]

3. European Chromosome 16 Tuberous Sclerosis Consortium. Identification and characterization of the tuberous sclerosis gene on chromosome 16. Cell. 1993;75(7):13051315. [CrossRef]

4. van Slegtenhorst M, de Hoogt R, Hermans C, et al. Identification of the tuberous sclerosis gene TSC1 on chromosome 9q34. Science. 1997;8(277)(5327):805-808.

5. Betts KA, Stockl KM, Yin L, et al. Economic burden associated with tuberous sclerosis complex in patients with epilepsy. Epilepsy Behav. 2020;112:107494. [CrossRef]

6. Northrup H, Koenig MK, Pearson DA, et al. Tuberous sclerosis complex. 1999 Jul 13. In: GeneReviews ${ }^{\circledR}$ [internet] Adam MP, Ardinger HH, Pagon RA, et al. eds.; 2020. Seattle (WA): University of Washington, Seattle:1993-2021.

7. Henske EP, Jóźwiak S, Kingswood JC, Sampson JR, Thiele EA. Tuberous sclerosis complex. Rev Primers. 2016;26(2):16035.

8. Northrup H, Krueger DA, International Tuberous Sclerosis Complex Consensus Group. International Tuberous Sclerosis Complex Consensus Group. Tuberous sclerosis complex diagnostic criteria update: recommendations of the 2012 International tuberous sclerosis Complex Consensus Conference. Pediatr Neurol. 2013;49(4):243254. [CrossRef]

9. Köhler S, Gargano M, Matentzoglu N, et al. The human phenotype ontology in 2021. Nucleic Acids Res. 2021;49(D1):D1207-D1217. [CrossRef]

10. Caban C, Khan N, Hasbani DM, Crino PB. Genetics of tuberous sclerosis complex: implications for clinical practice. Appl Clin Genet. 2016;21(10):1-8.

11. Çifcibaşı HS, Gülbal E, Erdoğan A, Demirci A, Demir S. Effective use of next generation sequencing for genetic diagnosis of a patient with a mosaic TSC2 variant. tmsj. 2018;5(2):43-46. [CrossRef]

12. Brook-Carter PT, Peral B, Ward CJ, et al. Deletion of the TSC2 and PKD1 genes associated with severe infantile polycystic kidney disease--a contiguous gene syndrome. Nat Genet. 1994;8(4):328-332. [CrossRef]

13. Ariyurek Y, Lantinga-van Leeuwen I, Spruit L, et al. Large deletions in the polycystic kidney disease 1 (PKD1) gene. Hum Mutat. 2004;23(1):99. [CrossRef]

14. Kozlowski P, Roberts P, Dabora S, et al. Identification of 54 large deletions/duplications in TSC1 and TSC2 using MLPA, and genotype-phenotype correlations. Hum Genet. 2007;121(3-4):389-400. [CrossRef]

15. Consugar MB, Wong WC, Lundquist PA, et al. CRISP Consortium. Characterization of large rearrangements in autosomal dominant polycystic kidney disease and the PKD1/TSC2 contiguous gene syndrome. Kidney Int. 2008;74(11):1468-1479. [CrossRef]
16. Schouten JP, McElgunn CJ, Waaijer R, et al. Relative quantification of 40 nucleic acid sequences by multiplex ligation-dependent probe amplification. Nucleic Acids Res. 2002;30(12):e57. [CrossRef]

17. Robinson JT, Thorvaldsdóttir H, Wenger AM, Zehir A, Mesirov JP. Variant review with the integrative genomics viewer. Cancer Res. 2017;77(21):e31-e34. [CrossRef]

18. Richards S, Aziz N, Bale S, et al. ACMG Laboratory Quality Assurance Committee. Standards and guidelines for the interpretation of sequence variants: a joint consensus recommendation of the American College of Medical Genetics and Genomics and the Association for Molecular Pathology. Genet Med. 2015;17(5):405-424. [CrossRef]

19. Karczewski KJ, Francioli LC, Tiao G, et. al., Genome Aggregation Database Consortium, Neale BM, Daly MJ, MacArthur DG. Nature. 2020;581(7809):434-443. [CrossRef]

20. Landrum MJ, Chitipiralla S, Brown GR, et al. ClinVar: improvements to accessing data. Nucleic Acids Res. 2020;48(D1):D835-D844. [CrossRef]

21. Sherry ST, Ward MH, Kholodov M, et al. DbSNP: the NCBI database of genetic variation. Nucleic Acids Res. 2001;29(1):308-311. [CrossRef]

22. Stenson PD, Mort M, Ball EV, et al. The Human Gene Mutation Database (HGMD ${ }^{\circledR}$ ) optimizing its use in a clinical diagnostic or research setting. Hum Genet. 2020t;139(10):1197-1207. [CrossRef]

23. Fokkema IF, Taschner PE, Schaafsma GC, et al. LOVD v.2.0: the next generation in gene variant databases. Hum Mutat. 2011;32(5):557-563. [CrossRef]

24. Rentzsch P, Witten D, Cooper GM, Shendure J, Kircher M. CADD: predicting the deleteriousness of variants throughout the human genome. Nucleic Acids Res. 2019;47(D1):D886-D894. [CrossRef]

25. Schwarz JM, Rödelsperger C, Schuelke M, Seelow D. MutationTaster evaluates disease-causing potential of sequence alterations. Nat Methods. 2010;7(8):575-576. [CrossRef]

26. Pollard KS, Hubisz MJ, Rosenbloom KR, Siepel A. Detection of nonneutral substitution rates on mammalian phylogenies. Genome Res. 2010;20(1):110-121. [CrossRef]

27. Yeo G, Burge CB. Maximum entropy modeling of short sequence motifs with applications to RNA splicing signals. J Comput Biol. 2004;11(2-3):377-394. [CrossRef]

28. Rosset C, Netto CBO, Ashton-Prolla P. TSC1 and TSC2 gene mutations and their implications for treatment in tuberous sclerosis Complex: a review. Genet Mol Biol. 2017;40(1):69-79. [CrossRef]

29. Sancak O, Nellist M, Goedbloed M, et al. Mutational analysis of the TSC1 and TSC2 genes in a diagnostic setting: genotype--phenotype correlations and comparison of diagnostic DNA techniques in tuberous sclerosis complex. Eur J Hum Genet. 2005;13(6):731-741. [CrossRef]

30. Jones AC, Shyamsundar MM, Thomas MW, et al. Comprehensive mutation analysis of TSC1 and TSC2-and phenotypic correlations in 150 families with tuberous sclerosis. Am J Hum Genet. 1999;64(5):1305-1315. [CrossRef]

31. Sasongko TH, Wataya-Kaneda M, Koterazawa K, et al. Novel mutations in 21 patients with tuberous sclerosis complex and variation of tandem splice-acceptor sites in TSC1 exon 14. Kobe J Med Sci. 2008;23(54(1)):E73-E81.

32. Oyazato Y, Iijima K, Emi M, et al. Molecular analysis of TSC2/PKD1 contiguous gene deletion syndrome. Kobe J Med Sci. 2011;57(1):E1-E10.

33. Atli EI, Atli E, Yalcintepe S, et al. Customized targeted massively parallel sequencing enables more precisely diagnosis of patients with epilepsy. Intern Med J. 2021 February 2. [CrossRef] [Online ahead of print].

34. Tyburczy ME, Dies KA, Glass J, et al. Mosaic and intronic mutations in TSC1/TSC2 explain the majority of TSC patients with no mutation identified by conventional testing. PLOS Genet. 2015;11(11):e1005637. [CrossRef]

35. Giannikou K, Lasseter KD, Grevelink JM, et al. Low-level mosaicism in tuberous sclerosis complex: prevalence, clinical features, and risk of disease transmission. Genet Med. 2019;21(11):2639-2643. [CrossRef]

36. Verhoef S, Bakker L, Tempelaars AM, et al. High rate of mosaicism in tuberous sclerosis complex. Am J Hum Genet. 1999;64(6):1632-1637. [CrossRef]

37. van Slegtenhorst M, Verhoef S, Tempelaars A, et al. Mutational spectrum of the TSC gene in a cohort of 225 tuberous sclerosis complex patients: no evidence for genotype-phenotype correlation. J Med Genet. 1999;36(4):285-289. 